\title{
The mode selection of rural land contract management right mortgage loan in china
}

\author{
$\mathrm{Ke} \mathrm{Li}$ \\ International Economy and Trade Institution, Jilin University of Finance and Economics, Jilin 130117, China
}

\begin{abstract}
According to the "separation of three powers" rules of rural land, the pilot projects of rural land contract management right mortgage loan are carried out nationwide. However, it is very difficult to spread in the whole country. In this case, this paper tries to find a mortgage model which is suitable for the present situation of our country and can avoid the dilemma as far as possible.
\end{abstract}

\section{The difficulties faced by the China's land contract management right mortgage}

The land contract management right refers to the right owned by citizens and collectives to operate and obtain the profit from the collective use or natural resources of collectively-used land and forests, mountains, grasslands, beaches, beaches, water surfaces and so on which are obtained in accordance with the contract [1-3]. In 2014, on the 1st central document, it clearly put forward "based on the implementation of collective ownership of rural land, stabilizing the contract rights of farmers, activating land management rights, allowing to mortgage financing on the land contract management right with financial institutions. In 2015, the 1st central document continued the reform idea of "fulfill the pilot work of land contract management rights mortgage loan and farmer housing property secured mortgage loan." The central document is intended to encourage the development of rural finance by encouraging and promoting the rural economy, increasing the income of farmers and realizing the integration of urban and rural areas. "Rural finance is the core of modern agricultural economy, but also the driving force of social and economic development." There are many ways of farmers financing, mainly including farmland mortgage loans, agricultural land shares enterprises, cooperatives, real estate certificates or homestead mortgage sale leaseback, farmland securitization, farmland capitalization, farmland sale and so on $[4,5]$. However, in China's rural areas, the property owned by farmers mainly includes the right to land contract management, housing and housing land use rights, agricultural means of production and agricultural products within the scope of housing. Among them, the land contracting right is the most important. In fact, there have been a lot of useful exploration on the rural land, woodland contract management rights mortgage financing in many parts of the country. Therefore, the reality, necessity and rationality of rural land contract management right mortgage financing have been proved [6-8]. As early as 2003, the CPC Central Committee and the State Council issued a "Decision on Accelerating Forestry Development", which clearly stipulated that forestry operators could legally mortgage their forests. Since then, around the forest tenure reform, we have carried out a series of exploration and innovation; and forest mortgages or forest pledge loans is of the main event as a service and a useful attempt of "three rural problem", also the forestry development and reform. In 2004, the State Forestry Administration had promulgated the Forest Resources Asset Mortgage Registration (Trial), which clarified the scope of forest land use rights that could not be mortgaged. In October 2008, the People's Bank of China and the China Banking Regulatory Commission jointly issued the Opinions on Accelerating the Innovation of Rural Financial Products and Services, calling for the selection of nine counties (cities) as pilot provinces to jointly promote rural financial products and services Way innovation work [9]. In March 2009, the People's Bank of China and China Banking Regulatory Commission once again issued a document entitled "Further Strengthening the Adjustment of Credit Structure to Promote the Steady and Rapid Development of the National Economy." The document clearly states: "Where there are conditions, land management rights mortgage loans can be explored. The first document in 2014, it was the first time the central government at the national policy level claimed that the "separation of powers" which includes the land rights of the land ownership, contract rights, the right to operate for is to support the realization of land contract management rights mortgage policy [10]. In line with this policy, in April the same year, the State Council issued" a number of opinions on the financial services of "three rural "development", clearly announced the trial of the rural

a Corresponding author: guotianbao1999@126.com 
land contract management rights mortgage loan is on the agenda. Although these explorations have achieved certain results, but also encountered legal requirements, land value assessment, land transfer and other bottlenecks.

\subsection{Legal obstacles}

From the theory of civil property rights law, land contract management right belongs to the important content of benefit right in other property rights. It has 10 provisions in Chapter 11 of China's "Property Law" about the right to land contract management. According to the provisions the land contract management contractor has the right to enjoy business autonomy, the right to receive benefits, to dispose the subcontracting and the requirements of discount compensation in accordance with the law. The mortgage financing right belongs to the land contractor's disposition. However, the existing legal provisions, the space for land contractors to mortgage finance is minimal. First, mortgages are limited. Secondly, the scope of land contractual management right mortgage is small.

\subsection{The plight of land assessment}

Since it is the right to mortgage finance on land contract management right, the value of land contract management right is the most important factor to decide financing scale. Compared with urban land evaluation mechanism, institutions and personnel, the rural land value assessment mechanism, institutions and personnel are almost blank, and the backwardness of the evaluation mechanism has hindered the efficiency of rural land mortgage transfer. The lack of scientific evaluation index and evaluation standard will result in different risks to the determination of land value whether too high or too low, which leads to the different evaluation standards of mortgage value of land management right.

\subsection{The plight of the transfer}

It may have some benefits when Land transfer is of a certain scale, and the need for further financing collateral. The problem is that, because of legal provisions and practical reasons, the transfer of land contracting right is not very smooth.

\section{The experience of foreign advanced experience for reference}

Based on the analysis of the model of rural land contract management right mortgage in some major capitalist countries and some countries and regions nearby, we can easily find out that the main function is to revitalize the existing rural resources (mainly rural land resources), to absorb more social funds to promote agricultural development, support rural construction. In addition, it can be seen by comparison that the common characteristics of agricultural land financing models in these developed countries or regions are mainly reflected in the following aspects.
Basic financial cooperation organizations have been established in various countries or regions (as will be seen in the case of domestic successful pilot projects). Because farmers and their undertakings are relatively fragmented and single, so from the perspective of reducing the risk of loans and transaction costs, it has a practical significance that farmers are spontaneously organized into cooperatives, and then to apply for agricultural real estate mortgage from the financial institutions and also can enhance the availability of mortgage loans.

These countries or regions have established their own exclusive land bank. For example, the German land mortgage cooperatives, the Japanese bank and the Federal Land Bank of United States are land banks being specifically for the rural areas, to support the agricultural development. Due to the weak nature of the agricultural industry itself, the high input costs, the long payback period and the thin profit, the ordinary commercial banks have no incentive to support agricultural development (the agricultural bank of our country is a good proof which transferred from the rural to the urban), hence cannot complete the task of supporting agricultural development, which result in establishing a special land bank necessarily.

All countries or regions issue land bonds. Agricultural land is real estate and lack of liquidity, and we must make the land resources flow to be functioning in agricultural land financing. Farmers use the land ownership certificate to apply for a mortgage from the land bank; but the land bank holding a large number of land ownership even cannot expand the scope of circulation, it is necessary to make land resources securitization. In the developed stock market, the land securities can be widely used to absorb social idle funds for agricultural construction, and the Government ensures the credit of land securities to enable it to repay debt on time.

The establishment of agricultural land financial system has been supported by the government in all aspects. The role of government is not only reflected in the formulation of policies, more importantly, in financial support. The government provides capital for land banks, subsidizes agricultural loans, provides interest-subsidized loans, reduces land bank reserves, and exempts taxes.

\section{China's existing rural land contract management right mortgage model and the ideal design}

The earlier pilot areas of rural land contract management right mortgage loans included Faku County in Liaoning Province, Maizhuang City in Shandong Province, Kaixian County in Chongqing and Jingmen City in Hubei Province, and gradually expanded to Anhui, Jiangsu, Zhejiang, Hunan, Jiangxi and other individual places. In the early stage of establishing the land contract management right mortgage pilot areas, the representative including the city of Shandong Province, the city of agricultural land mortgage model, Mingxi County, Fujian land mortgage loan model and Ningxia Tongxin County land mortgage model. 
From the above three pilot-related material analysis can be seen there is a clear common feature, that is, in order to enhance the ability of farmers to resist risks and also to reduce the risk of financial institutions to issue loans, farmers need to be spontaneously organized in various forms, or to establish land cooperatives, like the Maizhuang model or by setting up a land mortgage association like the Ningxia Tongxin County; in the context of the current household contract responsibility system in China, it is an effective way for farmers to get a bank mortgage by organizing it spontaneously. In addition, from the above case we also see the functions of local governments, whether it is policy-making or interest subsidies for agricultural loans and so on, the government has played a crucial role. At the same time, the success of the rural land mortgage system is also a good proof of the agricultural land mortgage in China which has a certain feasibility, and also has a good exploration and demonstration for the country to carry out the corresponding mortgage model. Later provinces or regions can refer to the successful experience of their predecessors, to develop agricultural land rights mortgage model combined with the actual situation of their own purposely.

\section{References}

1. State Council Comprehensive Rural Reform Working Group Office Task Force. The establishment of modern rural financial system research, Beijing: China Financial Economics Press, 2011.

2. S. L. Hua, Finance and Accounting, 2, 2010.

3. H. X. Liang, H. B. Chen, Property Law, 1997.

4. Guo Mingrui, Forum on Law, 1, 2010.

5. K. N. Wu, S. L. Ma, China Land Science, 4(2005).

6. J. C. Luo, etc, China's Agricultural Land Financial System, 2002.

7. J. Z. Luo, Q. Nie, Y. H. Zhang, China Rural Survey, 2003.

8. X. Y. Fu, Y. Yue, Wuhan Finance, 2010.

9. Y. M. Li, J. C. Luo. Research on Finance and Economics, 2005.

10. Z. R. Ceng, H. H. Wang, Three Rural Finance, 2010. 